\title{
GROWTH PERFORMANCE, BRAN OIL CHARACTERISTICS AND HULL VOLATILE CONSTITUENTS OF SOME RICE VARIETIES
}

\author{
ELSORADY, M.E. I. ${ }^{1}$, T. F. METWALLY ${ }^{2}$ and \\ ZENAB A. A. ABD-ALHAFEZ ${ }^{3}$
}

1- Oils and Fats Dept, Food Tech. Res. Inst., ARC, Giza, Egypt.

2- Rice Res. Dept., Field Crops Res. Inst., ARC, Kafer El-Sheikh, Egypt.

3- Medicinal and Aromatic Plants Res. Dept., Horticulture Res. Inst., ARC, Alexandria, Egypt

(Manuscript received 6 January 2015)

\begin{abstract}
$\mathrm{T}$ his study was undertaken to identify the differences among various aromatic rice genotypes in growth and yield as well as the characterization of bran oil and hull volatile constituents of both Egyptian Jasmine and Giza177 rice varieties under Egyptian condition. Six different rice genotypes namely; Egyptian Jasmine, IR74052-177-3-3, IR74053-144-2-3, Basmati 370 and PR26679-PI 3-1 Giza 177 as a check variety were transplanted at the experimental farm of RRTC during the rice growing seasons 2012 and 2013. Randomize complete block design with four replications was used. The main results revealed that the rice genotypes differed significantly $(P<0.05)$ with respect to agronomic studied characters under study. Egyptian Jasmine surpassed most of the other tested genotypes in these characters, while the check variety Giza177 recorded the lowest values of plant height, duration and number of panicle $\mathrm{m}^{-2}$. Giza177 produced the longest panicle with highest number of its branches and the highest number of filled grains panicle ${ }^{-1}$ with the lowest sterility $\%$ consequently produced the greatest grain yield $\mathrm{t} \mathrm{ha}^{-1}$. Chemicalphysical parameters of Egyptian Jasmine and Giza177 rice varieties bran oil were characterized. The free fatty acid, peroxide value, Saponification number and iodine value were recorded as $3.1 \%$ (as Oleic acid), 4.55 (meq $\mathrm{O}_{2} / \mathrm{kg}$ oil), 185.1 (mg KOH/g oil) and 92.64 ( $\mathrm{g} \mathrm{I}_{2} / 100 \mathrm{~g}$ oil), respectively. $\mathrm{Y}$-oryzanol is an important component in rice bran oil, it occurs in Egyptian Jasmine rice bran oil at a high level up to $1.8 \%$, where it serves as a natural antioxidant. Data also showed that Egyptian Jasmine rice bran oil had higher RSA and oxidative stability $59.23 \%$ and $22.86 \mathrm{~h}$, respectively than Giza177 rice bran oil. The fatty acid profile of Giza177 rice bran oil showed palmitic acid $(20.02 \%)$, stearic acid (1.95\%), oleic acid (45.99\%), linoleic acid $(28.07 \%)$ and linolenic acid $(1.40 \%)$ as major fatty acids. Results revealed that Egyptian Jasmine rice bran oil had higher oleic acid content and lower linoleic acid content than Giza177 rice bran oil. Percentage of hull constituents of Egyptian Jasmine was markedly higher than in hull of Giza 177. Moreover, the same trend was observed with total phenol content (TCP) and 2, 2-diphenyl-1-picrylhydrazyl (DPPH). Generally, the increase of total phenolic content led to an increase in DPPH \%, this result led to an increase of anti-oxidant activity in rice hulls.

Keywords: Egyptian Jasmine, growth performance, Rice bran oil, Antioxidant, Radical Scavenging Activity (RSA), Oxidative stability, Fatty acid composition, GC-MS, 5-Methylfurfural, 2-Ethylphenol, Eugenol and TPC.
\end{abstract}




\section{INTRODUCTION}

Rice (Oryza sativa, L.) is one of the most important staple food crops, it is considered one of the most important field crops in Egypt. Aromatic rice occupies an important position in world culture; not only because of high quality, but that they have been considered auspicious. Though aromatic rice contributes to a small share in the world market, it is valued at the highest price among all types of rice. The demand for aromatic rice is not expected to increase by consumers who have specific taste for them. Ashrafuzzaman et al. (2009) reported that aromatic rice varieties differed significantly $(P<0.05)$ with respect to leaf chlorophyll content, plant height, internode length, thousand grain weight and grain and straw yields. Varieties differed in morphological and yield and yield contributing traits. Metwally et al. (2012) reported that aromatic rice varieties varied significantly in most measurements of growth, grain yield and yield attributes, and added that Egyptian Jasmine variety having the highest values in most of growth and yield traits among the other tested varieties.

Rice milling yields $70 \%$ of rice (endosperm) as the major product, and byproducts consist of $20 \%$ rice husk, $8 \%$ rice bran, and $2 \%$ rice germ. Rice bran can be used as feed or as a source of rice bran oil. An earlier study reported that rice bran oil is an edible oil of unsaturated fatty acid (mono-unsaturated fatty acid $45 \%$ and polyunsaturated fatty acid 37\%). In comparison with most vegetable oils, rice bran oil has a qualitatively different composition of bioactive minor components, such as $\mathrm{Y}$ oryzanol, tocotrienols, and phytosterols. $\gamma$-Oryzanol derivatives in particular are found in only a very limited number of oils. $\mathrm{y}$-Oryzanol is a mixture containing compound ferulic acid ester of sterols and triterpene alcohols. It has antioxidant properties. Several studies have found that $\mathrm{y}$-oryzanol has various beneficial properties such as low plasma cholesterol, low cholesterol absorption and low disorders of menopause. The overall composition, nutrition profile, functional characteristics of rice bran oil reveals its wide application in healthy diet due to low saturated fat and cholesterol lowering activity in humans. The inherent fatty acid profile of rice bran oil makes it a natural candidate for use as frying oil without hydrogenation need, which is typically accompanied by the development of trans-fats and healthy food. (Kaewkool, 2011)

Rice bran oil's other components like tocotrienols and squalene have powerful anti-cancer and anti-ageing properties. Taking advantage of the valuable fact that micronutrient levels are so adequate in rice bran oil, it was considered that value of any other edible oil could be remarkably increased by addition of even small amounts of rice bran oil (Choudhary et al., 2013). 
Jasmine rice is very popular aromatic rice. The name implies the pleasant aroma and color of the jasmine flower. Because of its superior flavor and texture characteristics, the demand for jasmine rice in both the domestic and international markets increased over the years. Research conducted in the United States revealed that the most important acceptance factors for Asian consumers living in the United States were cooked rice appearance and aroma, and importing Thai jasmine rice was preferred over any other rice in that market (Meullenet et al., 2001). Recently, competition in producing and exporting aromatic rice has increased dramatically and aroma quality of rice becomes a major determinant for consumer.

Rice bran oil (RBO) is a miracle product obtained from the outer brown layer of rice. RBO is an excellent cooking medium because it is nutritionally superior, contains more micronutrients, longer shelf life, more stable at higher temperature, gives better taste \& flavour to food items, frying takes less time so saves energy and economical due to 15 percent less absorption of oil during frying (Choudhary et al., 2013).

Rice hulls (or rice husks) are the hard protecting coverings of grains of rice. In addition to protecting rice during the growing season, rice hulls can be put to use as building, fertilizer, insulation material, or fuel. Rice hulls are the outermost covering of the rice and come as organic rice hulls and natural rice hulls. Rice hulls are an inexpensive by-product of human food processing, serving as a source of fiber that is considered filler ingredient in cheap pet.

The objectives of this study were to 1) to evaluate the growth performance and grain yield of Egyptian Jasmine rice cultivar compared to four introduced aromatic genotypes and check variety, 2) evaluate the characterization of rice bran oil extracted from Egyptian Jasmine rice variety and compare it with those extracted from Giza 177 rice variety.

\section{MATERIALS AND METHODS}

\section{Genotype Screening for Aroma:}

Twenty rice genotypes were screened for their content of Aroma (Table 1), and the strongly scented ones were selected for further agronomic studies.

\section{Aroma test:}

From each genotype, 30 freshly harvested milled rice grains were introduced into $40 \mathrm{ml}$ glass test tube and provided with $20 \mathrm{ml}$ of distilled water. The tubes were wrapped with aluminum foil, and dipped into a boiling water bath for ten minutes. Then, the tubes were taken out and left to cool in the room temperature. The grain 
samples were categorized according to aroma scent into: strong (2), slight (1) and no aroma (0), according to standard evaluation system for rice (SES) of IRRI, (1996). To assure the aroma status in the samples of the 20 genotypes, this teat was repeated 6 times.

Table 1. Aromatic evaluation (reaction) for twenty genotypes.

\begin{tabular}{|c|c|c|c|c|c|c|c|}
\hline \multirow{2}{*}{ Genotype } & \multicolumn{6}{|c|}{ Test } & \multirow{2}{*}{ Reaction } \\
\hline & 1 & 2 & 3 & 4 & 5 & 6 & \\
\hline Giza 177 & 0 & 0 & 0 & 0 & 0 & 0 & None scented \\
\hline Giza 178 & 0 & 1 & 0 & 0 & 0 & 0 & None scented \\
\hline Sakha 101 & 0 & 0 & 0 & 0 & 0 & 0 & None scented \\
\hline E. Jasmine & 2 & 2 & 2 & 2 & 2 & 2 & Strong scented \\
\hline IR262-43-8-11 & 1 & 1 & 0 & 0 & 0 & 0 & Slightly scented \\
\hline IR44699-21-1-3-4 & 0 & 1 & 0 & 0 & 0 & 0 & Slightly scented \\
\hline IR54950-181-2-1-2-3 & 1 & 0 & 1 & 1 & 1 & 1 & Slightly scented \\
\hline IR65829-2B-95-P & 0 & 1 & 1 & 0 & 1 & 1 & Slightly scented \\
\hline IR65829-2B-2R-95-P & 1 & 1 & 1 & 0 & 1 & 1 & Slightly scented \\
\hline IR65610-38-2-4-2-6-3 & 1 & 1 & 0 & 0 & 1 & 1 & Slightly scented \\
\hline IR66438-167-3-3-2-3 & 1 & 1 & 0 & 0 & 1 & 1 & Slightly scented \\
\hline IR68726-3-1-2 & 1 & 0 & 0 & 1 & 1 & 1 & Slightly scented \\
\hline IR71137-234-2-2-3-3 & 0 & 1 & 1 & 1 & 1 & 1 & Slightly scented \\
\hline IR72860-80-3-3-3 & 0 & 1 & 1 & 1 & 1 & 1 & Slightly scented \\
\hline IR72870-19-2-2-3 & 1 & 1 & 1 & 0 & 1 & 1 & Slightly scented \\
\hline IR74052-177-3-3 & 2 & 1 & 2 & 2 & 2 & 2 & Strong scented \\
\hline IR74053-144-2-3 & 2 & 2 & 2 & 2 & 2 & 2 & Strong scented \\
\hline PR26679-PI 3-1 & 1 & 2 & 2 & 2 & 2 & 2 & Strong scented \\
\hline СТ9852-3-2-1-2-4P-M & 0 & 0 & 0 & 0 & 0 & 0 & None scented \\
\hline Basmati 370 & 2 & 2 & 1 & 2 & 2 & 2 & Strong scented \\
\hline
\end{tabular}

Score: $0=$ None scented,$\quad 1=\quad$ Slightly scented,$\quad 2=$ Strong scented 


\section{Agronomic study:}

The strong scented genotypes (Table 2.); Egyptian Jasmine, IR74052-177-3-3, IR74053-144-2-3, Basmati 370 and PR26679-PI 3-1 as well as Giza 177 (as a check), were transplanted at the experimental farm of Rice Research and Training Center, Sakha to evaluate agronomic traits among the previously mentioned genotypes under transplanting conditions. The genotypes were allocated in a randomize complete block design with four replications in two successive rice seasons; 2012 and 2013. The previous crop was barely in the two seasons. Seeds at the rate of $96 \mathrm{~kg} \mathrm{ha}^{-1}$ were soaked in water for $24 \mathrm{hr}$ then incubated for $48 \mathrm{hr}$ to hasten early germination. Pregerminated seeds were uniformly broadcasted in the nursery on $7^{\text {th }}$ and $1^{\text {st }}$ May of the two seasons, respectively. The permanent field was well prepared, i.e. plowed twice followed by good wet leveling. Seedlings were carefully pulled from the nursery after 30 days from sowing and distributed through the plots. Seedlings were manually transplanted into $15 \mathrm{~m}^{2}$ subplots in 20X20 cm spacing at the level of 2-3 seedlings hill ${ }^{-1}$. Nitrogen fertilizer was added as urea form $(46.5 \% \mathrm{~N})$. Two third of $\mathrm{N}$ was applied as basal application, and the other third was top dressed at 30 days after transplanting. All plots received identical cultural treatments

The agronomic studied characters were; flag leaf area $\left(\mathrm{cm}^{2}\right)$, plant height $(\mathrm{cm})$, duration (day), number of panicle $\mathrm{m}^{2}$, panicle length $(\mathrm{cm})$, number of primary branches panicle ${ }^{-1}$, number of filled grains panicle ${ }^{-1}$, spikelet sterility\% and grain yield $\left(\mathrm{t} \mathrm{ha}^{-1}\right)$.

Table 2. Rice genotypes, parentage, type and origin.

\begin{tabular}{|l|l|l|l|l|}
\hline No & Genotypes & Parentage & Type & Origin \\
\hline 1 & Giza 177 & (Giza 171/Yu mji No.1//PiNo.4) & Japonica & Egypt \\
\hline 2 & E. Jasmine & IR262-43-8-11/KDML105 & Indica & Egypt \\
\hline 3 & IR74052-177-3-3 & IR44699-21-1-3-4/IR66438-167-3-3-2-3 & Indica & IRRI \\
\hline 4 & IR74053-144-2-3 & IR00A103/IR70177-32-2-1-3-2 & Indica & IRRI \\
\hline 5 & Basmati 370 & Native genotype & Indica & India \\
\hline 6 & PR26679-PJ3-1 & HINOHIKRI/IR64 & Indica & Philippines \\
\hline
\end{tabular}

*IRRI: International Rice Research Institute, Los Baños, Philippines 


\section{Rice bran oil study \\ Extraction of rice bran oil}

The samples of rice bran were obtained as a by-product after milling of Egyptian Jasmine rice and Giza 177 (season 2013). The oil from rice bran was extracted immediately after rice milling through solvent extraction technique as described in AOCS (1998); hexane used as solvent was recovered by Rotary Evaporator Apparatus. The extracted oil was stored in dark brown glasses at $\left(-20{ }^{\circ} \mathrm{C}\right)$ until analysis.

\section{Oil content}

Oil content of rice bran was determined by means of the Soxhelt fat extraction apparatus using hexane at $60-80^{\circ} \mathrm{C}$ boiling point as described by A.O.A.C. (2005).

\section{Analytical determinations}

Analytical procedures: Free fatty acids, Iodine value, Peroxide value (PV), saponification value and unsaponifiable matter of extracted oil were determined as various standards AOCS methods (AOCS 1998). Iodine values were calculated utilizing the following equation (AOCS, 1998):

$$
\begin{gathered}
\mathrm{IV}=\left(0.95 \times \mathrm{C}_{16: 1}\right)+\left(0.86 \times \mathrm{C}_{18: 1 \mathrm{n}-9}\right)+\left(1.732 \times \mathrm{C}_{18: 2 n-6}\right)+\left(2.616 \times \mathrm{C}_{18: 3 n-3}\right)+ \\
\left(0.785 \times \mathrm{C}_{20: 1}\right)
\end{gathered}
$$

\section{Oryzanol content determination}

Oryzanol content of rice bran oil was determined by a spectrophotometric method (Choudhary et al., 2013) by dissolving $0.01 \mathrm{ml}$ of the sample in $10 \mathrm{ml}$ of hexane and reading the absorbance at $314 \mathrm{~nm}$ in a $1-\mathrm{cm}$ cell (JENWAY $6405 \mathrm{UV} / \mathrm{Vis}$ .Spectrophotometer, England). The oryzanol content was calculated by using the formula: [(A/W) X (100/358.9)]

Where $A$ is the absorbance of the sample, $W$ is the weight of the sample in gram/100 ml, 358.9 is specific extinction coefficient for oryzanol.

\section{Oxidative stability}

Oxidative stability was evaluated by the Rancimat method (Gutierrez, 1989). Stability was expressed as the oxidation induction time (hours), measured with the Rancimat 679 apparatus (Metrohm Co., Switzerland), using an oil sample of $5 \mathrm{~g}$ heated to $100^{\circ} \mathrm{C}$ with air flow of $20 \mathrm{~L} / \mathrm{h}$ 


\section{Radical Scavenging Activity (RSA) Toward 2,2-diphenyl-1-picrylhydrazyl (DPPH) Radicals}

2,2-diphenyl-1-picrylhydrazyl (DPPH) radical scavenging activity was measured using the method described by (Choudhary et al., 2013). This assay is based on the determination of the concentration of 2,2-diphenyl-1-picrylhydrazyl (DPPH) methanolic solution, after adding the antioxidants. DPPH concentration is reduced by the existence of an antioxidant at $515 \mathrm{~nm}$ and the absorption gradually disappears with time. A $0.1 \mathrm{mM}$ methanolic solution of DPPH was prepared. The oil samples (1 $\mathrm{ml}$ after tenfold dilution) were placed in test tubes and a 2-ml aliquot of DPPH methanolic solution was added and the mixture was vortexed for $20 \mathrm{~s}$ at ambient temperature. Against a blank of pure methanol without DPPH, the decrease in absorption at $515 \mathrm{~nm}$ was measured in 1-cm quartz cells after 30 min of mixing, using a spectrophotometer (JENWAY 6405 UV/Vis .Spectrophotometer, England). RSA toward DPPH radicals was estimated from the differences in absorbance of methanolic DPPH solution with or without sample (control) and the inhibition percent was calculated using the following equation:

$$
\begin{gathered}
\% \text { inhibition }=[\text { (absorbance of control - absorbance of test } \\
\text { sample }) / \text { absorbance of control }] \times 100 .
\end{gathered}
$$

\section{Gas chromatography analysis}

Fatty acid composition: The fatty acid was analyzed according to the Ce 1-62 injection method (AOCS, 1998). The gas-chromatograph used was Agilent 6890 series GC apparatus provided with a DB-23 column $(60 \mathrm{~m} \times 0.32 \mathrm{~mm} \times 0.25 \mu \mathrm{m})$ was used. Oven temperatures were $150^{\circ} \mathrm{C}$ ramped to $195^{\circ} \mathrm{C}$ at $5^{\circ} \mathrm{C} \mathrm{min}{ }^{-1}$, ramped to $220^{\circ} \mathrm{C}$ at $10^{\circ} \mathrm{C} \mathrm{min}^{-1}$ and flow rate was $1.5 \mathrm{~min}^{-1}$. Fatty acids results after the previous procedures steps were transformed into methyl esters and directly injected into the GC.

\section{Rice hull Volatile:}

The essential oil of rice hulls extract was done according to British Pharmacopoeia (1963), by solvent method, in order to extract the essential oil.

The rice hull extract was analyzed with GC-MS (Thermo Electron Corporation) with flame ionization detector (FID) on a fused silica 132 capillary column DB-5, $25 \mathrm{~m}$ in length, $0.32 \mathrm{~mm}$ i.d., and $0.5 \mathrm{~mm}$ film thickness. 133 Helium was used as the carrier gas with a flow rate of $1.6 \mathrm{ml} / \mathrm{min}$; the detector 134 temperature was $260{ }^{\circ} \mathrm{C}$, the oven temperature was programmed to increase from 130 to $280^{\circ} \mathrm{C}$ at a rate of $4^{\circ} \mathrm{C} / \mathrm{min}$. The split injector was heated at $250^{\circ} \mathrm{C}$, the split 136 ratio was $15: 1$. Data were processed on a DP 800 integrator. The percentage of majors constituents were 
estimated by measuring the peak area of the different compounds of the chromatogram according to Gunther and Joseph (1978).

\section{Determination of radical scavenging activity (DPPH) in rice hulls extract}

The ability to scavenge the stable free radical (1, 1-diphenyl-2-picrylhydrazyl) (DPPH) was determined based on the method of Choudhary et al., (2013) as mentioned before.

\section{Determination of total phenolic content in rice hulls extract}

Total phenolic content (TPC) of rice hulls extract was determined according to the method described by Makkar et al. (1997). Four hundred $\mu$ of sample was taken in the test tube; then, $1.0 \mathrm{ml}$ of Folin-Ciocalteu reagent (diluted 10-fold with distilled water) and $0.8 \mathrm{ml}$ of $7.5 \%$ sodium carbonate were added. After vortexing the reaction mixture, the tube was placed in a dark place for $40 \mathrm{~min}$ and the absorption at $765 \mathrm{~nm}$ was measured against a blank. The total phenolic content was expressed as gallic acid equivalents in $\mathrm{mg} / \mathrm{g}$ of methanol extract.

\section{RESULTS AND DISCUSSION}

Data in Tables ; 3, 4 and 5 showed that there were significant differences among the tested genotypes in all agronomic characters. Data in Table 3. showed that the highest values of flag leaf area were recorded by IR74053-144-2-3 and Egyptian Jasmine without significant difference between them. The tallest plants were those of Egyptian Jasmine while Giza 177 displayed the shortest plants. The shorter plant height in Giza 177 was due to shorter internode length. Taller plants produced longest internode than shorter ones. Plant height is mostly governed by the genetic makeup of the cultivar, but the environmental factors also influence it. These results are in agreement with data presented by Ashrafuzzaman et al. (2009) and Faruq et al. (2011). Days to maturity varied significantly among the studied genotypes, Egyptian Jasmine needed more days to mature compared with the other genotypes while, Giza 177 required the shortest duration to mature. Karim et al. (2007) who studied 41 aromatic rice genotypes for variability and genetic parameter analysis and found highly significant mean sum of square due to genotypes for days to maturity. they reported that variation for days to maturity was attributed by genetic constituent rather than environment. Ashrafuzzaman et al. (2009) reported that breeding efforts are underway to develop short lived varieties with high yield potential. 
Table 3. Flag leaf area, Plant height and duration of different rice genotypes in 2012 and 2013 seasons.

\begin{tabular}{|l|c|c|c|c|c|c|}
\hline \multirow{2}{*}{ Genotype } & \multicolumn{2}{|c|}{ Flag leaf area $\left(\mathrm{cm}^{2}\right)$} & \multicolumn{2}{c|}{ Plant height (cm) } & \multicolumn{2}{c|}{ Duration (day) } \\
\cline { 2 - 7 } & 2012 & 2013 & 2012 & 2013 & 2012 & 2013 \\
\hline Giza 177 & 40.4 & 39.0 & 93.0 & 92.7 & 125.0 & 124.7 \\
Egyptian Jasmine & 49.0 & 54.9 & 123.3 & 124.7 & 153.0 & 152.7 \\
IR74052-177-3-3 & 34.5 & 33.2 & 103.0 & 102.3 & 127.0 & 126.7 \\
IR74053-144-2-3 & 51.5 & 51.3 & 113.3 & 116.0 & 136.0 & 135.7 \\
Basmati 370 & 35.7 & 37.3 & 111.3 & 113.0 & 143.0 & 142.7 \\
PR26679-PI 3-1 & 29.7 & 35.8 & 115.3 & 114.0 & 140.7 & 139.7 \\
\hline L.S.D.0.05 & 9.16 & 10.02 & 7.395 & 7.152 & 1.135 & 0.996 \\
\hline
\end{tabular}

There were significant differences among the genotypes in number of total panicles per $\mathrm{m}^{2}$ (Table 4). The highest values of number of panicles $\mathrm{m}^{-2}$ were recoded in Egyptian Jasmine, while the lowest values were recorded in IR74053-144-2-3 and Basmati 370. It was observed that Egyptian Jasmine produced the longest panicles which were statistically similar to those of IR74053-144-2-3 compared to the other varieties (Table 4). Faruq et al. (2011) and Nahida Islam et al. (2013) found a significant variation in length of panicle among different aromatic genotypes. Regarding number of primary branches per panicle, data in Table (4) indicted that significant differences among the six rice varieties for this trait were observed in the two seasons of study. Giza 177 gave the highest number primary branches per panicle followed by Basmati 370 while, PR26679-PI 3-1 gave the lowest number. The reason of difference in effective tillers hill-1 is the genetic makeup of the variety, which is primarily influenced by heredity (Nahida Islam et al. 2013).

Table 4. Number of panicle per $\mathrm{m}^{2}$, panicle length and number of primary branches per panicle of different rice genotypes in 2012 and 2013 seasons.

\begin{tabular}{|l|c|c|c|c|c|c|}
\hline \multirow{2}{*}{\multicolumn{2}{|c|}{ Genotype }} & \multicolumn{2}{|c|}{ No. of panicle $\mathrm{m}^{-2}$} & \multicolumn{2}{c|}{ Panicle length (cm) } & \multicolumn{2}{c|}{$\begin{array}{c}\text { No. of primary branches } \\
\text { panicle }^{-1}\end{array}$} \\
\cline { 2 - 7 } & 2012 & 2013 & 2012 & 2013 & 2012 & 2013 \\
\hline Giza 177 & 305.0 & 341.7 & 21.83 & 20.83 & 13.67 & 13.33 \\
Egyptian Jasmine & 465.0 & 475.0 & 27.50 & 28.10 & 11.67 & 12.67 \\
IR74052-177-3-3 & 355.0 & 364.3 & 24.50 & 24.33 & 12.00 & 12.00 \\
IR74053-144-2-3 & 438.0 & 462.7 & 27.17 & 27.27 & 12.00 & 12.33 \\
Basmati 370 & 446.7 & 472.7 & 23.67 & 24.00 & 12.83 & 13.00 \\
PR26679-PI 3-1 & 291.0 & 323.3 & 22.83 & 23.83 & 10.17 & 10.43 \\
\hline L.S.D.0.05 & 19.9 & 16.2 & 2.83 & 2.71 & 1.39 & 1.30 \\
\hline
\end{tabular}


Results presented in (Table 5) showed that number of filled grains panicle ${ }^{-1}$ was the highest with the tested genotype Giza 177 while, the lowest value was recorded with the genotype IR74052-177-3-3. Egyptian Jasmine had much higher sterility percentage which might be due to genetic characters of Egyptian Jasmine. Giza 177 had the highest grain yield $\mathrm{t} \mathrm{ha}^{-1}$ followed by Egyptian Jasmine. Grain yield, in fact, is the out-product of its main components. The increase in one or more of there components without decrease in the others will led to an increase in grain yield. Therefore, the high grain yield of Giza 177 was the logical result due to increase in number of primary branches per panicle and number of filled grains per panicle as well as low sterility percentage. Faruq et al. (2011) indicated that low yield is a common phenomenon of aromatic rice and consequently rice breeders are trying to develop the agronomic characters to gain a better grain yield. Similar yielding trend was also reported by Metwally et al. (2012) and Nahida Islam et al. (2013).

Table 5. No. of filled grains, spikelet sterility $\%$ and grain yield of different rice genotypes in 2012 and 2013 seasons.

\begin{tabular}{|l|c|c|c|c|c|c|}
\hline \multirow{2}{*}{\multicolumn{1}{|c|}{ Genotype }} & \multicolumn{2}{|c|}{$\begin{array}{c}\text { No. of filled grains } \\
\text { panicle }\end{array}$} & \multicolumn{2}{c|}{ Spikelet sterility \% } & \multicolumn{2}{c|}{ Grain yield t ha ${ }^{-1}$} \\
\cline { 2 - 7 } & 2012 & 2013 & 2012 & 2013 & 2012 & 2013 \\
\hline Giza 177 & 192.88 & 200.37 & 3.61 & 2.81 & 10.18 & 10.34 \\
Egyptian Jasmine & 183.55 & 193.88 & 18.56 & 16.35 & 9.353 & 9.80 \\
IR74052-177-3-3 & 128.68 & 154.76 & 19.46 & 9.63 & 8.427 & 8.29 \\
IR74053-144-2-3 & 187.26 & 190.87 & 4.11 & 4.71 & 8.613 & 8.47 \\
Basmati 370 & 174.22 & 181.84 & 5.72 & 3.41 & 8.593 & 8.95 \\
PR26679-PI 3-1 & 178.53 & 181.54 & 7.12 & 4.61 & 7.513 & 7.40 \\
\hline L.S.D.0.05 & 34.76 & 56.77 & 11.34 & 9.51 & 0.73 & 0.82 \\
\hline
\end{tabular}

\section{Oil content of rice bran}

Oil content of Egyptian Jasmine rice bran oil (JRBO) and Giza 177 rice bran oil (GRBO) are shown in Table (6). JRBO had higher oil content (21.01\%) than GRBO (19.1\%). This result agreed with Anwar et al. (2005).

\section{Chemical and Physical Characteristics:}

Free fatty acids levels are the first measure of RBO quality. Data in Table (6) shows free fatty acids (FFA) \% as oleic acid of JRBO and GRBO. The crude rice bran oil of GRBO was superior in FFA (3.5\%, as oleic acid) than crude rice bran oil of JRBO (3.1\%, as oleic acid). 
Table 6. Physicochemical characteristics of studied rice bran oils.

\begin{tabular}{|l|c|c|}
\hline \multicolumn{1}{|c|}{ Characteristics } & $\begin{array}{c}\text { Egyptian Jasmine } \\
\text { (JRBO) }\end{array}$ & Giza 177 (GRBO) \\
\hline Oil content \% (on dry weight basis) & 21.01 & 19.1 \\
\hline FFA \% (as Oleic acid) & 3.1 & 3.5 \\
\hline Peroxide value (meq $\mathrm{O}_{2} / \mathrm{kg}$ oil) & 4.55 & 4.62 \\
\hline Iodine value (g I $/ 100 \mathrm{~g}$ oil) & 92.64 & 106.92 \\
\hline Saponification number (mg KOH/g oil) & 185.1 & 3.7 \\
\hline Unsaponifiable matter (\%) & 4.4 & 189.5 \\
\hline
\end{tabular}

The peroxide value (PV) is a measure of primary oxidation process. The PV of JRBO was 4.55 meq $\mathrm{O}_{2} / \mathrm{kg}$ lower than that of GRBO which was 4.62 meq $\mathrm{O}_{2} / \mathrm{kg}$ (Table 6). None of the oils analyzed exceeded the maximum peroxide values for refined oil and crude oil limits (10 and 15 meq $\mathrm{O}_{2} / \mathrm{kg}$, respectively), which reported by CODEX standards (2005).

The iodine value (IV) is a measure of the unsaturation of the oils. It is one of the parameters used to measure the oil quality (Haryati et al., 1998). Table (6) presents the IV of JRBO and GRBO. Results revealed that IV of JRBO was $92.64 \mathrm{~g}$ $\mathrm{I}_{2} / 100 \mathrm{~g}$ oil and $106.92 \mathrm{~g} \mathrm{I}_{2} / 100 \mathrm{~g}$ oil for GRBO. These results agreed with results of fatty acid composition (Table 8), as GRBO had more USFA than JRBO.

Saponification number (SN) is an indicator of the average molecular weight and, hence, chain length. It is inversely proportional to the molecular weight of the lipid. The SN of JRBO and GRBO were 185.1 and $189.5 \mathrm{mg} \mathrm{KOH} / \mathrm{g}$ oil, respectively (Table 6) and fell in the 180-195 range reported for the rice bran oil (CODEX, 2005).

Crude rice bran oil contains $\sim 96 \%$ of saponifiable fractions and $~ 4 \%$ unsaponifiable fractions of lipids which include phytosterols, sterol esters, triterpene alcohols, hydrocarbons, and tocopherols (Rubalya Valantina et al., 2010).The content of unsaponifiable matters were $4.4 \%$ for JRBO and $3.7 \%$ for GRBO (Table 6 ) were both in the range $3-7 \%$ for rice bran oil reported by Anwar et al. (2005).

\section{y-oryzanol Content:}

The $y$-oryzanol of Egyptian Jasmine rice bran oil was 1. 8\% (Table: 7). Data also showed that Giza177 rice bran oil had 1.2\% Y-oryzanol content. Kaewkool, (2011) cited that $\mathrm{y}$-oryzanol is a mixture of ferulic acid esters of sterol and triterpene alcohols, it occurs in rice bran oil at a level of 1 to $2 \%$, where it serves as a natural antioxidant. 
Table 7. Relation between $\mathrm{Y}$-oryzanol $\mathrm{L}_{\mathbf{L}}$ DPPH Radical scavenging Activity and oxidative stability of studied rice bran oils.

\begin{tabular}{|l|c|c|}
\hline \multicolumn{1}{|c|}{ Characteristics } & $\begin{array}{c}\text { Egyptian Jasmine } \\
\text { (JRBO) }\end{array}$ & Giza 177 (GRBO) \\
\hline Y -Oryzanol (\%) & 1.8 & 1.2 \\
\hline $\begin{array}{l}\text { Radical Scavenging Activity (RSA) Toward DPPH Radicals } \\
\text { (\%) }\end{array}$ & 59.23 & 54.23 \\
\hline Oxidative stability (h) & 22.86 & 20.56 \\
\hline
\end{tabular}

\section{Radical Scavenging Activity (RSA) Toward DPPH Radicals:}

This assay is based on the reduction of DPPH radicals in methanol which causes an absorbance drop at $515 \mathrm{~nm}$. In this study, the radical scavenging activity towards DPPH free radicals was expressed as percent inhibition. The DPPH free radical scavenging activities of JRBO and GRBO are shown in Table (7). Ranking order of percent inhibition showed was JRBO>GRBO after 30 minutes. The high RSA in JRBA is related to high $\mathrm{Y}$-oryzanol content $(1.8 \%)$. These results agreed with Choudhary et al. (2013).

Higher RSA of JRBO could be due to higher presence of oryzanol $(1.8 \%)$ and oleic acid. Research studies have reported that oleic acid is more stable towards oxidation during storage and cooking. Scientific studies reported that the higher alpha tocopherol and oryzanol content, the higher DPPH scavenging activity would be (Choudhary et al., 2013).

\section{Oxidative stability:}

Data in Table (7) showed that JRBO had higher oxidative stability (22.86 h) than GRBO (20.56 h), indicating a high resistance to oxidation and stability. The results revealed that $y$-oryzanol was related to the corresponding oxidative stability for the oils obtained from rice bran. Anwar et al. (2005) mentioned that high oxidative stability of rice bran oil compared with those of conventional vegetable oils could be attributed to a significant higher level of $\mathrm{C}_{18: 1}$, which is less prone to oxidation than polyenoics. Moreover, a high resistance to oxidation of rice bran oil might be explained due to the presence of high content of $\mathrm{y}$-oryzanol and tocopherols.

\section{Fatty acid composition:}

The fatty acid composition of JRBO and GRBO (Figure: 1 and Table: 8) indicated that oleic and linoleic acids were 74.06 and 79.44\%, respectively. Kaewkool, (2011) cited that oleic and linoleic fatty acids constitute more than $70 \%$ of fatty acids of glycerides. 

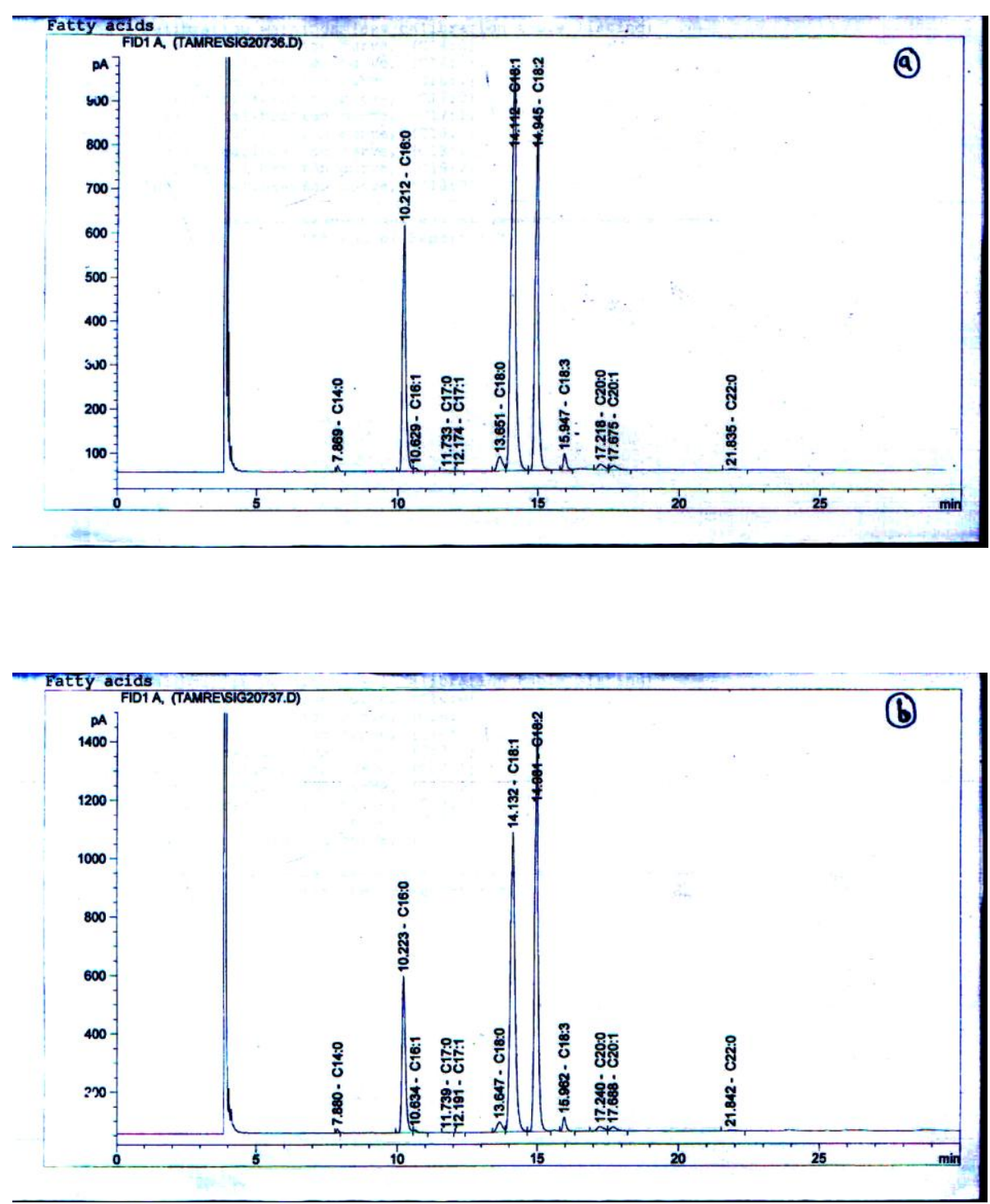

Figure 1. Gas chromatography of fatty acid composition of (a) Egyptian Jasmine and (b) Giza 177 rice bran oil. 
Table 8. Fatty acid composition of studied rice bran oils.

\begin{tabular}{|c|c|c|}
\hline Fatty acid & Egyptian Jasmine (JRBO) & $\begin{array}{c}\text { Giza } 177 \\
\text { (GRBO) }\end{array}$ \\
\hline $\mathrm{C}_{14: 0}$ & 0.30 & 0.24 \\
\hline$C_{16: 0}$ & 20.02 & 15.17 \\
\hline $\mathrm{C}_{16: 1}$ & 0.28 & 0.31 \\
\hline$C_{17: 0}$ & 0.09 & 0.04 \\
\hline $\mathrm{C}_{17: 1}$ & 0.04 & 0.03 \\
\hline$C_{18: 0}$ & 1.95 & 1.58 \\
\hline$C_{18: 1}$ & 45.99 & 40.14 \\
\hline$C_{18: 2}$ & 28.07 & 39.30 \\
\hline$C_{18: 3}$ & 1.40 & 1.32 \\
\hline$C_{20: 0}$ & 0.99 & 0.87 \\
\hline$C_{20: 1}$ & 0.69 & 0.75 \\
\hline$C_{22: 0}$ & 0.18 & 0.25 \\
\hline$\Sigma \mathrm{SFA}$ & 23.53 & 18.15 \\
\hline$\Sigma$ USFA & 76.47 & 81.85 \\
\hline MUSFA & 47.00 & 41.23 \\
\hline PUSFA & 29.47 & 40.62 \\
\hline MUSFA / PUSFA & 1.59 & 1.02 \\
\hline
\end{tabular}

*SFA- Saturated fatty acids, USFA- Unsaturated fatty acids, MUSFA-monounsaturated fatty acids, PUSFApolyunsaturated fatty acids

Table (8) shows the fatty acid composition of different rice bran oils. The content of total saturated fatty acids (SFA); myristic $\left(C_{14: 0}\right)$, palmitic $\left(C_{16: 0}\right)$, stearic $\left(\mathrm{C}_{18: 0}\right)$ and arachidic $\left(\mathrm{C}_{20: 0}\right)$ acids, in JRBO and GRBO were 23.53 and 18.15 , \% respectively.

The JRBO and GRBO were found to contain a high level of monounsaturated fatty acids (MUSFA) up to $47.00 \%$ and $41.23 \%$, respectively. The level of oleic acid $\left(\mathrm{C}_{18: 1}\right)$, accounted for $45.99 \%$ and $40.14 \%$, respectively of the total fatty acids. The content of linoleic acid $\left(C_{18: 2}\right)$ in JRBO and GRBO was 28.07 , and $39.30 \%$, respectively. 
The content of linolenic acid $\left(\mathrm{C}_{18: 3}\right)$ in JRBO and GRBO was found to be 1.40, and $1.32 \%$ respectively. This lower linolenic acid content renders rice bran oil more resistant to oxidation than soybean (Kaewkool, 2011).

The present fatty acid analysis of the rice bran oil produced from Egyptian varieties showed that oleic acid was the predominant fatty acid followed by linoleic and palmitic acid. These results agreed with Anwar et al. (2005).

The Japan Ministry of Health and Welfare suggests fatty acid ratio of saturated/ monounsaturated/polyunsaturated for the healthy edible oils as 1: 1.5: 1 . The fatty acid composition of JRBO falls in the desirable ratios. As the rice bran oil is unique in its fatty acid composition, it is considered one of the highest qualities of vegetable oil. As with humans, a number of fatty acids are required in animal diets. It appears that rice bran oil is roughly equal to other vegetable oils in supplying fatty acid requirements but unique in its fatty acid composition. In consideration of this and above properties, rice bran oil has much to offer in caring for nutritional and health needs of the pets and other animals in addition to human beings (Anwar et al., 2005).

The higher oxidative stability of JRBO, compared to GRBO is due to the high oleic acid (monounsaturated) and low polyunsaturated fatty acid content of the triacylglycerols. In addition, JRBO contains high level of $\mathrm{y}$-Oryzanol. These compounds have antioxidative effects and possess anti-hydrolytic effects during oxidation process.

\section{Rice hull volatile analysis:}

Generally, data presented in Tables (9 and 10) and Fig. (2) showed that rice hulls extract of $E$. Jasmine gave the highest mean value of major constituents percentage compared with Giza177. Also Jasmine rice hulls gave the highest mean value of the total phenolic content and the same trend (the highest mean value) of $\mathrm{DPPH} \%$. On the other hand, Giza177 rice hulls gave the lowest value in the total phenolic content and low percentage of DPPH. Generally the increase of total phenolic content led to an increase in DPPH \%, which led to an increase of anti-oxidant activity in rice hulls.

The chromatographic fractionation of rice hulls extract showed that the main compounds are 2-Ethylphenol, 2Methoxy-4-methylphenol (4-Methylguaiacol), 4Methoxyphenol and 4-Ethyl-2-methoxyphenol (4-Ethylguaiacol).On the other hand, the results indicated that Jasmine rice hulls extract gave the highest percentage of DPPH, and most of main compounds. This can be explained by the fact that the increase in percentage of main compounds for most essential oils leads to an increase in the percentage of DPPH (Rice-Evans et al., 1996) 
Table 9. Percentage of major constituents in rice hull extract

\begin{tabular}{|c|c|c|}
\hline \multirow[t]{2}{*}{ Volatile compound } & \multicolumn{2}{|c|}{$\begin{array}{l}\text { Percentage of major volatile constituents } \\
\qquad(\%)\end{array}$} \\
\hline & E. Jasmine & Giza177 \\
\hline $\begin{array}{c}\text { 5-Methyl-2-furancarboxaldehyde } \\
\text { (5-Methylfurfural) }\end{array}$ & 8.04 & 6.39 \\
\hline 2,3-Dihydrobenzofuran Phenols & 7.24 & 5.92 \\
\hline Eugenol & 3.06 & 2.91 \\
\hline 2-Ethylphenol & 17.35 & 14.48 \\
\hline $\begin{array}{l}\text { 2-Methoxy-4-methylphenol } \\
\text { (4-Methylguaiacol) }\end{array}$ & 16.65 & 14.87 \\
\hline 4-Methoxyphenol & 16.79 & 13.35 \\
\hline $\begin{array}{l}\text { 4-Ethyl- 2-methoxyphenol } \\
\text { (4-Ethylguaiacol) }\end{array}$ & 15.80 & 12.72 \\
\hline 2-Mehtoxy-4-vinylpheonl & 7.15 & 6.07 \\
\hline $\begin{array}{c}\text { 2-Methoxy-4-(1-propenyl)phenol } \\
\text { (Trans-isoeugenol) }\end{array}$ & 1.83 & 2.09 \\
\hline
\end{tabular}

Table 10. Total phenol content (TCP) and DPPH\% (2,2-diphenyl-1-picrylhydrazyl) in rice hull extract

\begin{tabular}{|c|c|c|}
\hline \multirow{2}{*}{ Entry } & $\begin{array}{c}\text { TPC } \\
(\mathrm{mg} \mathrm{GAE} / \mathrm{gm} \mathrm{DW})^{* *}\end{array}$ & DPPH \% \\
\hline E. Jasmine & 38.5 & 21.7 \\
\hline Giza177 & 33.5 & 18.5 \\
\hline
\end{tabular}

** TCP Data expressed as $\mathrm{mg}$ of gallic acid equivalents per $\mathrm{g}$ dry weight (DW). 

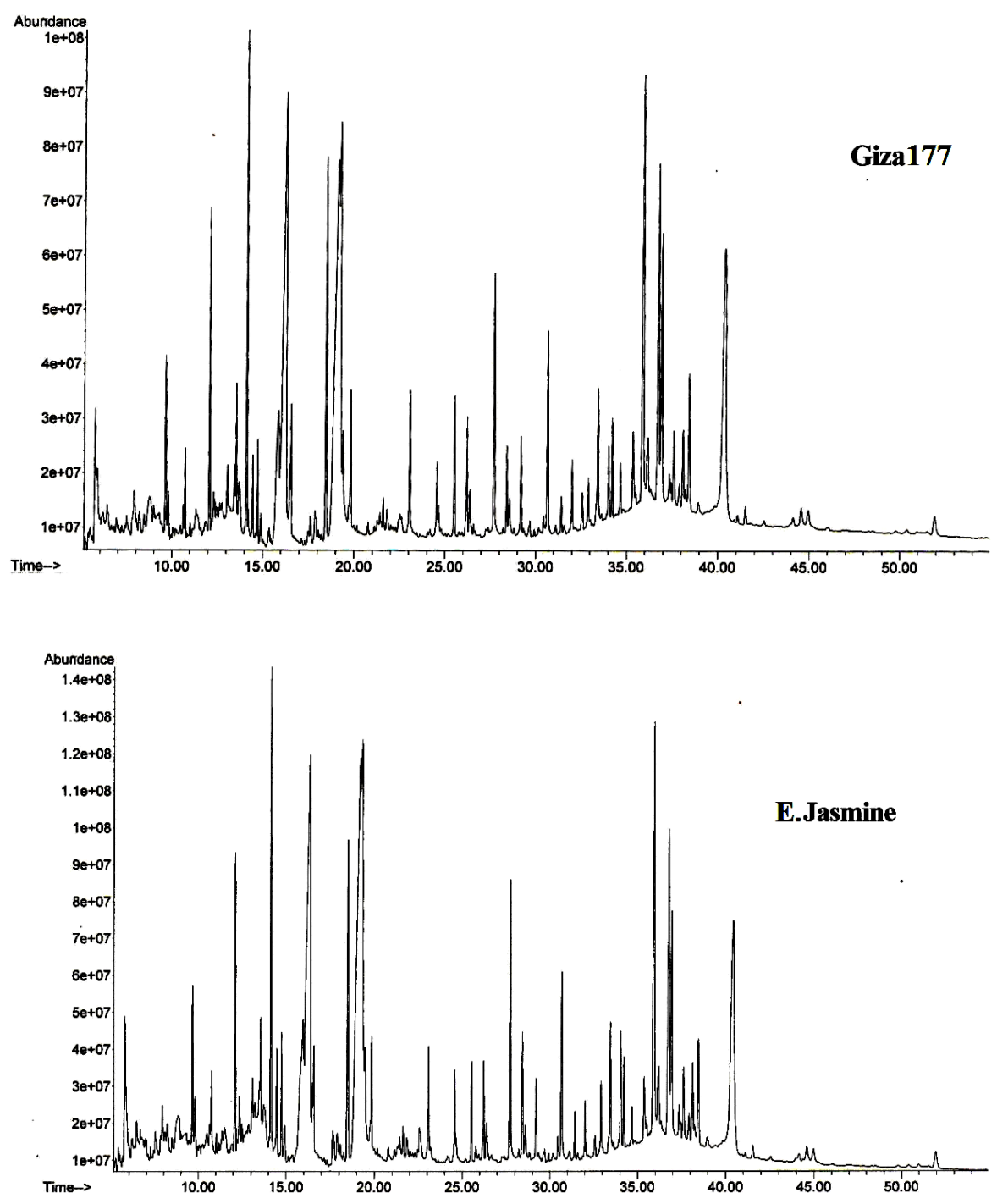

Fig. 2. Typical GC-MS chromatograms of rice hull extract

\section{REFERENCES}

1. Anwar, F., T. Anwar, and Z. Mahmood. 2005. Methodical Characterization of Rice (Oryza Sativa) Bran Oil from Pakistan. Gras. Aceit. 56: 125-134.

2. AOAC. 2005. Official methods of Analysis of AOAC International $18^{\text {th }}$ ed. Gaithersburg, Maryland, USA.

3. AOC. 1998. Official and tentative methods of the American oil chemists society (5th ed.). American Oil Chemists Society, 35 East Waker Drive, Chicago, Illinois, USA.

4. Ashrafuzzaman, M., M.R. Islam, M.R. Ismail, S.M. Shahidullah and M.M. Hanafi. 2009. Evaluation of six aromatic rice varieties for yield and yield contributing characters. Int. J. Agric. Biol., 11: 616-620.

5. British Pharmacopoeia. 1963. Determination of Volatile Oil in Drugs. The Pharmaceutical Press, London. 
6. Choudhary, M., K.Grover, and G. Kaur. 2013. Fatty acid composition, oxidative stability, and radical scavenging activity of rice bran oil blends. International journal of food and nutritional sciences, Vol.2, Iss.1, Jan-Mar 2013, 33-43.

7. CODEX. 2005. JOINT FAO/WHO FOOD STANDARDS PROGRAMME, CODEX COMMITTEE ON FATS AND OILS, Nineteenth Session, London, United Kingdom, 2125 February 2005.

8. Faruq G., Y. H. Yin, A. Masitah, N. Afnierna, N. Abdul Majid, N. Khalid, and M. Osman. 2011. Analysis of aroma and yield components of aromatic rice in Malaysian tropical environment. AJCS 5(11):1318-1325.

9. Gunther, z., and S. Joseph. 1978. Hand Book Series in Chromatography. CRC press, Inc.

10. Gutierrez, R. F. 1989. Determinacion de la estabilidad oxidativa de a- ceites de oliva virgenes : Comparacidn entre el mètodo del oxigen. active (AOM) y el mètodo Rancimate. Grasas y Aceites, 40, 1 - 5.

11. Haryati, T., Y.B. Che Man, , H.M. Ghazali, , B.A. Asbi, and L. Buana. (1998). Determination of iodine value of palm oil based on triglyceride composition. J Am Oil Chem Soc 75: 789-792.

12. IRRI. 1996. Standard Evaluation System for rice SES. International Rice Research Institute. Los Banos, Philippines.

13. Kaewkool, P. 2011. Characterization of cold pressed organic rice bran oil. Asian Journal of Food and Agro-Industry, As. J. Food Ag-Ind., 4(01), 16-21

14. Karim D. U., M.N.A. Sarkar, M. A. Siddique, Miah Khaleque and M. Z. Hasnat. 2007. Variability and Genetic Parameter Analysis in Aromatic Rice. Int. J. Sustain. Crop Prod. 2(5):15-18.

15. Makkar,H., K. Becker, K. Abel and H. Pawelzik. 1997. Nutrient contents, rumen protein degradability and antinutritional factors in some colour- and white-flowering cultivars of Vicia faba beans. J. Sci. Food Agric. 75: 511 - 20.

16. Metwally, T.F., M.M. El-Malky, A.A. Glelah and A.S. Gharieb. 2012. Performance of Elite Aromatic Rice Varieties under Different Sowing Dates under Egyptian Condition. J. Plant Production, Mansoura Univ. 3(2): 311-333.

17. Meullenet, J.F., V.K. Griffin, K. Carson, G. Davis, S. Davis, J. Gross, J.A. Hankins, E. Sailor, C. Sitakalin, , S. Suwansri and A.L. Vasquez Caisido. 2001. Rice external preference mapping for Asian consumers living in the United States. Journal of Sensory Study, Vol. 16, pp. 73-94.

18. Nahida Islam, Md. Yamin Kabir, Sanjoy Kumar Adhikary, and Md. Sarwar Jahan. 2013. Yield Performance of Six Local Aromatic Rice Cultivars. Journal of Agriculture and Veterinary Science. 6(3): 58-62.

19. Rice-Evans, C., N. Miller and G. Paganga. 1996. Structure antioxidant activity relationships of flavonoids and phenolic acids. Free Radic. Biol. Med., 20: 933-956.

20. Rubalya Valantina, S., P. Arockia Sahayaraj, and A. Angelin Prema. 2010. Antioxidant stability in palm and rice bran oil using simple parameters. RASAYAN J.Chem, Vol.3, No.1, 44-50. 


\section{صفات نمو و خصائص زيت رجيع الكون والمركبات الطيارة في قثرة حبوب بعض أصناف الأرز}

محمد السيد إسماعيل الصردى' و تامر فاروق متولي `و زينب على أحمد عبد الحافظ”

$$
\begin{aligned}
& \text { 1- - مركز البحوث الزراعية - معطز بحوث تكنولوجيا الأغنية - قسم بحوث الزيوت والدهون - الجيزة - مصر. }
\end{aligned}
$$

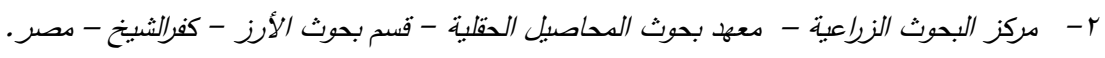

$$
\begin{aligned}
& \text { r- مركز البحوث الزراعية ـ معرط بحوث البساتين .قسم بحوث النباتات الطبية و العطرية ـ الأسكندرية ـمصر. }
\end{aligned}
$$

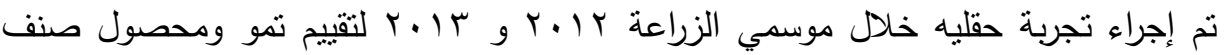

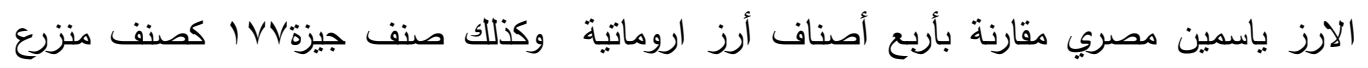
وبالاضافة الى خصائص زيت رجيع الكون المستخلص من صنف أرز الياسمين المصرى. نم استخدام

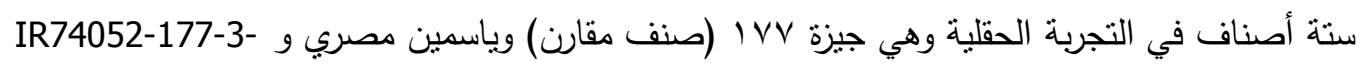

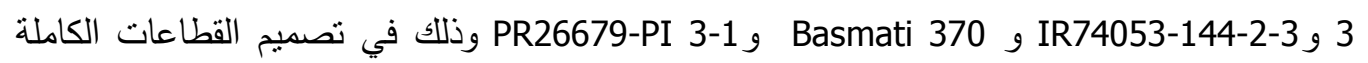

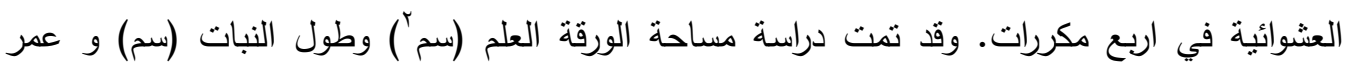

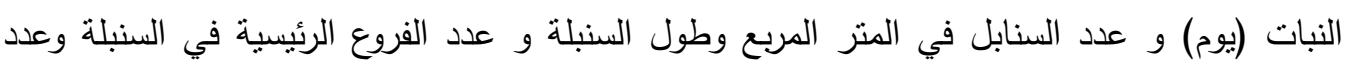

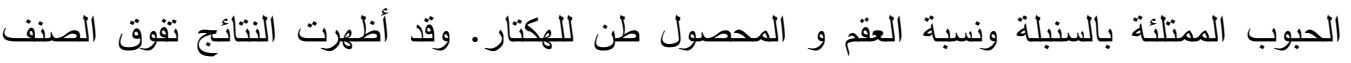

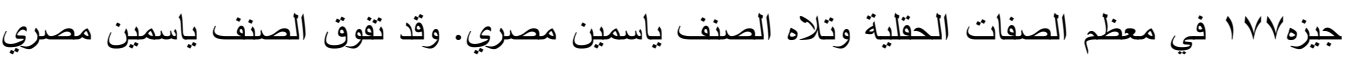

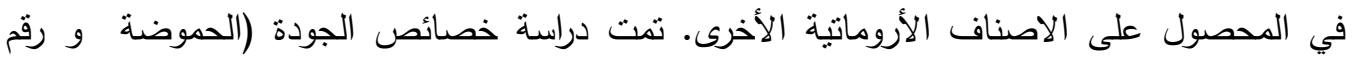

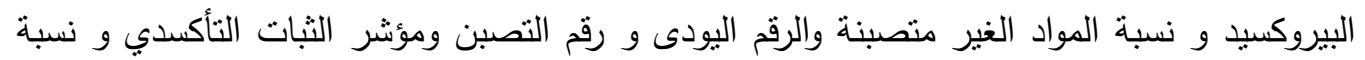

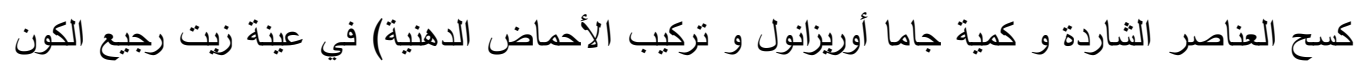
المستخلص من صنف أرز الياسمين المصرى و مقارنته بزيت رجيع الكون المستخلص من صنف جيزة IVV

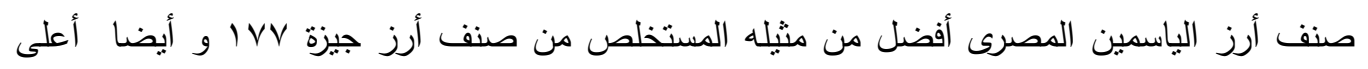
تركيز من نسبه مضاد الأكسدة (جاما أوريزانول) و أعلى ثبات تأكسدى و كسح للعناصر الثاردة. كما أوضحت النتائج أن زيت رجيع الكون المستخلص من صنف أرز الياسمين المصرى يحتوى على نسبة الئاد

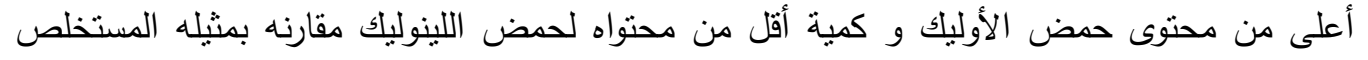

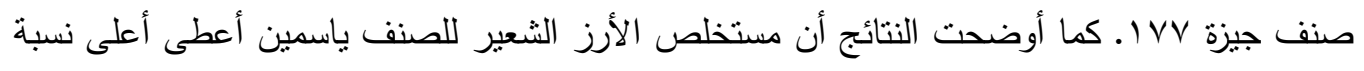

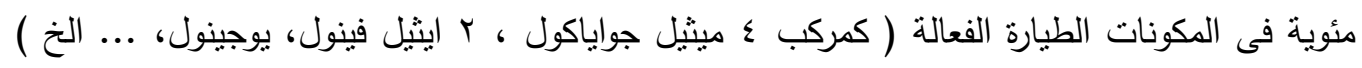
مقارنة بمستخلص الأرز الثعير صنف جيزة ، كذللك أعطى الصنف ياسمين أعلى محتوى فى الفينولات

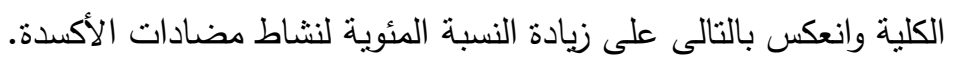

